\title{
Analysis of Foreign and Domestic Transactions Effect on Stock Returns in Service Sector Companies Listed in Indonesia Stock Exchange
}

\author{
Randy Heriyanto ${ }^{1}$, Fitra Oliyan ${ }^{2}$, Gustati ${ }^{3}$ \\ \{heriyantorandy@gmail.com ${ }^{1}$, oliyan.fitra@gmail.com ${ }^{2}$, gustati1602@yahoo.com ${ }^{3}$ \} \\ Politeknik Negeri Padang, Padang, Indonesia
}

\begin{abstract}
The growth of the service sector is the fastest development in 2017 reaching more than $40 \%$. This will generate great interest in both domestic and foreign investors. This study aims to examine the effect of foreign transactions on domestic transactions on stock returns in service sector companies in 20162018. The data used in this study are secondary data obtained from daily stock price reports and daily foreign (buy) and domestic buy (sell) data. The technical analysis used is descriptive analysis and Pearson correlation analysis using IBM SPSS Statistics 2.0. Based on testing conducted will be known later whether there is a relationship between foreign transactions on stock returns.
\end{abstract}

Keywords: Foreign Transactions, Domestic Transactions, Stock Returns

\section{Introduction}

The capital market makes it easy for investors to invest their capital in companies. Stock is one of the investment type that is preferred and is considered to be able to provide benefits in a fairly short period of time. This stock trading history will also be stored in the Indonesia Stock Exchange data which will later be recapitulated in the Composite Stock Price Index (CSPI). Buy and sell shares occur due to the expectation of changes in the form of an increase in the price of shares that have been purchased so as to make a profit. The rise and fall of stock prices is influenced by certain factors. Therefore, investors always want information that can help make decisions in buying and selling shares in order to obtain maximum profit.

To get a large profit will be followed by commensurate risk, this is in accordance with the axiom of financial management, namely High Risk-High Return. [1]. Return is one indicator of a company's profit. Return is one of the things that provides direction for investors to invest and is also a reward for the courage of investors to bear the risk of their investments so that investors will look for companies that allow providing substantial returns to invest, companies One of them is the service sector, service sector companies are companies that carry out activities in terms of trade both large and small, offering services to consumers and offering the products they have[2]. Stock trading in this sector is also in demand by foreign investors. The value of this transaction can be seen in the recapitulation of domestic transactions and foreign transactions on the Indonesia Stock Exchange website. 
There is a relationship between the value of foreign transactions on stock returns[1]. The percentage of foreign ownership and dividends has a significant effect on stock prices, while sales growth, market risk and market return have no significant effect on stock prices[3]. Domestic transactions on the Indonesia Stock Exchange (IDX) annually dominate the stock transactions on the Indonesia Stock Exchange. The increase certainly cannot be separated from the role of the Indonesian government who campaigned for Yuk Nabung Shares. With an increase in stock transactions every year by domestic investors will affect the price of shares on the Indonesia Stock Exchange. Trading frequency, trading volume and trading day simultaneously have a significant effect on stock returns[4].

First, Fransiska (2013) [5] argued that all listed companies in 2011-2012 showed that foreign transactions have significant effect on stock price, especially LQ-45 index. Manggal (2013)[6] found that local investors who follows trend buying foreign stock transaction have effect on increasing and decrasing of stock price. Adji (2014) [1] added more macroeconomic variables, they are inflation, interest rate, and exchange rate. The results, they do not have signficant effect on foreign transaction. In contrast, this study will focus more on domestic and foreign transcation arround service sectors in particular

Several companies in the service sector are included in the LQ45 index, whose company liquidity is higher than other companies. In 2017, banking sector shares ranked first with a growth of $40.19 \%$ year to date. This is inseparable from the development of financial technology in the current era which will greatly facilitate the users of financial services such as banks and other financial services sectors in enjoying the services provided and will affect the company's performance which indirectly will lead to investor interest in investing in these shares. Therefore this research needs to be done so that investors get a picture of the relationship between foreign and domestic transactions on stock returns in service sector companies listed on the Indonesia Stock Exchange.

\section{Descriptive Analysis of Foreign and Domestic Transactions and Stock Returns}

Companies that have been grouped in service sectors, the relationship between domestic transaction variables, foreign transactions and stock returns will be seen where domestic transactions and foreign transactions are seen from domestic net buy and foreign net buy on a daily basis. Then for stock returns can be seen from the difference between the closing price and opening price divided by the opening price of the stock on a daily basis. The number of domestic net buy (sell), foreign net buy (sell) and the percentage increase or decrease in stock returns to the sample companies in 2016-2018 in this study.

Table 1. Number of Domestic Transactions, Foreign Transactions and Percentage of Changes in Stock Returns per Sector

\begin{tabular}{|c|l|l|l|l|}
\hline NO & \multicolumn{1}{|c|}{ SECTOR } & $\begin{array}{c}\text { FOREIGN NET BUY } \\
\text { (SELL) }\end{array}$ & $\begin{array}{c}\text { DOMESTIC NET } \\
\text { BUY (SELL) }\end{array}$ & $\begin{array}{c}\text { STOCK } \\
\text { RETURN }\end{array}$ \\
\hline 1 & $\begin{array}{l}\text { Property Sector, Real Estate and } \\
\text { Building Construction }\end{array}$ & 7.195 .088 .962 .735 & 7.209 .137 .038 .171 & $2261 \%$ \\
\hline 2 & $\begin{array}{l}\text { Infrastructure Sector, Utilities and } \\
\text { Transportation }\end{array}$ & -24.825 .007 .998 .402 & 24.825 .007 .877 .402 & $-201 \%$ \\
\hline 3 & Financial Sector & 2.762 .044 .258 .752 & -2.763 .447 .628 .717 & $3056 \%$ \\
\hline
\end{tabular}




\begin{tabular}{|c|l|l|l|l|}
\hline 4 & $\begin{array}{l}\text { Trade, Services and Investment } \\
\text { Sector }\end{array}$ & 8.199 .739 .576 .360 & -8.199 .645 .998 .480 & $2265 \%$ \\
\hline \multicolumn{2}{|c|}{ TOTAL } & -21.058 .313 .126 .025 & 21.071 .051 .288 .376 & $7381 \%$ \\
\hline
\end{tabular}

The most sales are marked with negative net buy (sell), where the number of foreign transactions is more selling than the number of buying actions - 21,058,313,126,025 where The sector that most conducted sales transactions occurred in the infrastructure, utilities and transportation sectors, which amounted to $-24,825,007,998,402$. On the contrary, the majority of those conducting buying transactions were found in domestic transactions with a total of $21,071,051,288,376$ where the sectors that carried out the most buying actions were also found in the infrastructure, utilities and transportation sectors totaling $24,825,007,998,402$. For changes in stock returns the total percentage change in overall stock prices showed a positive result of $7322 \%$ where the highest stock return changes were found in the financial sector with a percentage of stock returns of $3056 \%$ with an average increase of $4 \%$ per day. While the highest decrease of all sectors was found in the Infrastructure, Utilities and Transportation Sector with a decrease of $-201 \%$ with an average decline of $-0.4 \%$ per day.

Table 2. Number of Domestic Transactions, Foreign Transactions and Percentage of Changes in Stock Returns per Sub Sector

\begin{tabular}{|c|c|c|c|c|}
\hline NO & SECTOR & $\begin{array}{l}\text { FOREIGN NET BUY } \\
\text { (SELL) }\end{array}$ & $\begin{array}{l}\text { DOMESTIC NET BUY } \\
\text { (SELL) }\end{array}$ & $\begin{array}{l}\text { STOCK } \\
\text { RETURN }\end{array}$ \\
\hline \multicolumn{5}{|c|}{ Property, Real estate and Building Construction Sector } \\
\hline 1 & Property and Real Estate Sub Sector & -8.977 .820 .452 .663 & 8.991 .868 .528 .099 & $645 \%$ \\
\hline 2 & Building Construction Sub Sector & 1.782 .731 .489 .928 & -1.782 .731 .489 .928 & $1616 \%$ \\
\hline \multicolumn{5}{|c|}{ Infrastructure, Utilities and Transportation Sector } \\
\hline 3 & Energy Sub Sector & -5.569 .187 .777 .687 & 5.569 .187 .777 .687 & $-70 \%$ \\
\hline 4 & $\begin{array}{l}\text { Toll Road, } \\
\text { Ports, Airports and the like Sub } \\
\text { Sector }\end{array}$ & -4.767 .855 .439 .605 & 4.767 .855 .439 .605 & $3 \%$ \\
\hline 5 & Telecommunication Sectors & -8.694 .771 .512 .870 & 8.694 .771 .391 .870 & $-6 \%$ \\
\hline 6 & Transportation Sub Sectors & -195.373 .016 .578 & 195.373 .016 .578 & $-124 \%$ \\
\hline 7 & $\begin{array}{l}\text { Non Building Constructions Sub } \\
\text { Sectors }\end{array}$ & -5.597 .820 .251 .662 & 5.597 .820 .251 .662 & $-4 \%$ \\
\hline \multicolumn{5}{|c|}{ Finance Sector } \\
\hline 8 & Bank Sub Sectors & 1.580 .146 .097 .887 & -1.581 .516 .842 .152 & $1399 \%$ \\
\hline 9 & Financial Institution Sub Sectors & -509.521 .572 .233 & 509.488 .185 .033 & $524 \%$ \\
\hline 10 & Securities Company Sub Sectors & -130.964 .232 .200 & 130.964 .993 .700 & $331 \%$ \\
\hline 11 & Insurance Sub Sectors & 1.822 .383 .965 .298 & -1.822 .383 .965 .298 & $802 \%$ \\
\hline \multicolumn{5}{|c|}{ Trade, Service and Investment Sector } \\
\hline 12 & Large Trade Sub Sectors & 610.564 .428 .554 & -610.564 .428 .554 & $583 \%$ \\
\hline 13 & Retail Trade Sub Sectors & 2.127 .575 .330 .022 & -2.127 .583 .467 .642 & $68 \%$ \\
\hline 14 & $\begin{array}{l}\text { Restaurants, Hotels and Tourism } \\
\text { Sub Sectors }\end{array}$ & 5.363 .663 .308 .637 & -5.363 .663 .308 .637 & $603 \%$ \\
\hline 15 & Advertising, Printing dan Media Sub & 2.065 .607 .408 .078 & -2.065 .607 .408 .078 & $704 \%$ \\
\hline
\end{tabular}




\begin{tabular}{|r|l|r|r|r|}
\hline & Sectors & & & \\
\hline 16 & Health Sub Sectors & 11.385 .524 .300 & -11.385 .524 .300 & $63 \%$ \\
\hline 17 & $\begin{array}{l}\text { Computer Services and Other } \\
\text { Devices Sub Sectors }\end{array}$ & 195.623 .341 .958 & -195.521 .723 .958 & $92 \%$ \\
\hline 18 & Investment Company Sub Sectors & -2.131 .726 .043 .589 & 2.131 .726 .141 .089 & $-46 \%$ \\
\hline 19 & Other Trade Sub Sectors & -42.953 .721 .600 & 42.953 .721 .600 & $198 \%$ \\
\hline \multicolumn{2}{|r|}{ TOTAL } & -21.058 .313 .126 .025 & 21.071 .051 .288 .376 & $7381 \%$ \\
\hline
\end{tabular}

The sub-sector that has the most selling transactions marked by negative net buy (sell) is foreign transactions in the property and real estate sub-sector amounting to $-8,977,820,452,663$ then followed by the telecommunications communications sub-sector. of $-8,694,771,512,870$, the opposite of which carried out the most buying transactions marked by positive net buy (sell) was also found in the property and real estate sub sector of $8,977,820452,663$ then followed by the telecommunications subsector of $8,694,771,391.870$. For the highest change in stock return, the increase was in the building construction sub-sector with the percentage increase in stock returns during 2016-2018 of $1616 \%$ with an average increase of $2 \%$ per day. While the highest decline in stock returns occurred in the transportation sub-sector by $124 \%$ with an average decline of $-0.1 \%$ per day.

\section{Pearson Correlation Analysis of Foreign and Domestic Transactions Effect On Stock Returns}

Table 3. Joint Service Sector Correlation Test Results

\begin{tabular}{|c|c|c|c|c|}
\hline & & $\begin{array}{l}\text { Foreign } \\
\text { Transaction }\end{array}$ & $\begin{array}{l}\text { Domestic } \\
\text { Transaction }\end{array}$ & Stock Return \\
\hline \multirow[b]{3}{*}{ Foreign Transaction } & Pearson Correlation & 1 & $-1,000^{* * *}$ & $134^{* *}$ \\
\hline & Sig. (2-tailed) & & ,000 & 000 \\
\hline & $\begin{array}{l}\mathrm{N} \\
\text { Pearson Correlation }\end{array}$ & $\begin{array}{r}731 \\
-1,000^{* *}\end{array}$ & 731 & $\begin{array}{r}731 \\
-.134^{* *}\end{array}$ \\
\hline \multirow{3}{*}{ Domestic Transaction } & Sig (2-tailed) &, 000 & &, 000 \\
\hline & & 731 & 731 & 731 \\
\hline & Pearson Correlation &, $134^{* *}$ &,$- 134^{* *}$ & 1 \\
\hline \multirow[t]{2}{*}{ Stock Return } & Sig. (2-tailed) &, 000 &, 000 & \\
\hline & $\mathrm{N}$ & 731 & 731 & 731 \\
\hline
\end{tabular}

From the results of simple correlation analysis (r) foreign transactions obtained Pvalue $(\mathrm{Sig}=0,000)<0,000$, then $\mathrm{H} 0$ is rejected, so there is a correlation between foreign transactions with changes in stock returns with $(r)$ is 0.134 . From these results indicate that there is a relationship but very low between foreign transactions on stock returns because it is in the range of $0.00-0.199$. But the direction of the relationship is positive because the value of $r$ is positive, which means an increase in foreign transactions will trigger an increase in stock 
returns. For domestic transactions obtained Pvalue $(\mathrm{Sig}=0,000)<0.05$, then $\mathrm{H} 0$ is rejected, so there is a correlation of domestic transactions to changes in stock returns with (r) is -0.134 . From these results it shows that there is a relationship but it is very low. However, the direction of the relationship is negative because the value of $r$ is negative, which means an increase in domestic transactions will trigger a decrease in stock returns.

\subsection{Correlation Between Service Sectors}

\subsubsection{Property, Real estate and Building Construction Sector}

Correlation test results and hypothesis testing of the Property Sector, Real Estate and Building Construction, researchers present in the table as follows:

Table 3. Correlation Test Results for Property, Real Estate and Building Construction Sector

\begin{tabular}{|c|c|c|c|c|}
\hline & & $\begin{array}{l}\text { Foreign } \\
\text { Transaction }\end{array}$ & $\begin{array}{l}\text { Domestic } \\
\text { Transaction }\end{array}$ & $\begin{array}{l}\text { Stock } \\
\text { Return }\end{array}$ \\
\hline & Pearson Correlation & 1 & $-1,000^{* *}$ & ,041 \\
\hline Foreign & Sig. (2-tailed) & &, 000 & 271 \\
\hline \multicolumn{5}{|l|}{ Transaction } \\
\hline \multirow{2}{*}{ Domestic } & Pearson Correlation & $-1,000^{* *}$ & 1 &,- 041 \\
\hline & Sig. (2-ta1led) & ,000 & & ,271 \\
\hline \multirow{2}{*}{ Transaction } & $\mathrm{N}$ & 731 & 731 & 731 \\
\hline & Pearson Correlation &, 041 &,- 041 & 1 \\
\hline \multirow[t]{2}{*}{ Stock Return } & Sig. (2-tailed) & , 271 & ,271 & \\
\hline & $\mathrm{N}$ & 731 & 731 & 731 \\
\hline
\end{tabular}

From the results of simple correlation analysis (r) foreign transactions obtained Pvalue $(\mathrm{Sig}=0.271)>0.05$, then H0 is accepted, so there is no correlation of foreign transactions to changes in stock returns with (r) is 0.041 . For domestic transactions, it is found that P-value $(\mathrm{Sig}=0.271)>0.05$, then $\mathrm{H} 0$ is accepted, so there is no correlation of domestic transactions with changes in stock returns with (r) is 0.041 . From these results we can conclude that there is no foreign transaction relationship, domestic transactions on stock returns in the Property, Real Estate and Building sector companies.

\subsubsection{Infrastructure, Utilities and Transportation Sector}

Correlation test results and hypothesis testing from the Infrastructure, Utilities and Transportation Sector, researchers present in the table as follows: 
Table 4. Infrastructure, Utilities and Transportation Sector Correlation Test Results

\begin{tabular}{|l|l|r|r|}
\hline & & $\begin{array}{l}\text { Foreign } \\
\text { Transaction }\end{array}$ & \multicolumn{2}{l|}{$\begin{array}{l}\text { Stock } \\
\text { Return } \\
\text { Transaction }\end{array}$} \\
\hline Foreign Pearson Correlation \\
Transaction Sig. (2-tailed)
\end{tabular}

**. Correlation is significant at the 0.01 level (2-tailed).

From the results of simple correlation analysis (r) foreign transactions obtained Pvalue $(\mathrm{Sig}=0.287)>0.05$, then $\mathrm{H} 0$ is accepted, so there is no correlation of foreign transactions on changes in stock returns with (r) is 0.039 . For domestic transactions, it is found that P-value $(\mathrm{Sig}=0,287)>0.05$, then $\mathrm{H} 0$ is accepted, so there is no correlation of domestic transactions with changes in stock returns with (r) is -0.039 . From these results we can conclude that there are no foreign transactions, domestic transactions related to stock returns in the Infrastructure, Utilities and Transportation Sector.

\subsubsection{Finance Sector}

Correlation test results and hypothesis testing from the financial sector, researchers present in the table as follows:

Table 5. Financial Sector Correlation Test Results

\begin{tabular}{|c|c|c|c|c|}
\hline & & $\begin{array}{l}\text { Foreign } \\
\text { Transaction }\end{array}$ & $\begin{array}{l}\text { Domestic } \\
\text { Transaction }\end{array}$ & $\begin{array}{l}\text { Stock } \\
\text { Return }\end{array}$ \\
\hline $\begin{array}{l}\text { Foreign } \\
\text { Transaction } \\
\text { Domestic } \\
\text { Transaction }\end{array}$ & $\begin{array}{l}\text { Pearson Correlation } \\
\text { Sig. (2-tailed) } \\
\mathrm{N} \\
\text { Pearson Correlation } \\
\text { Sig. (2-tailed) } \\
\mathrm{N}\end{array}$ & $\begin{array}{r}1 \\
731 \\
-1,000^{* *} \\
, 000 \\
731\end{array}$ & \begin{tabular}{r|}
$-1,000^{* *}$ \\
000 \\
731 \\
1 \\
731
\end{tabular} & $\begin{array}{r}, 279^{* *} \\
, 000 \\
731 \\
-, 279^{* *} \\
, 000 \\
731\end{array}$ \\
\hline
\end{tabular}




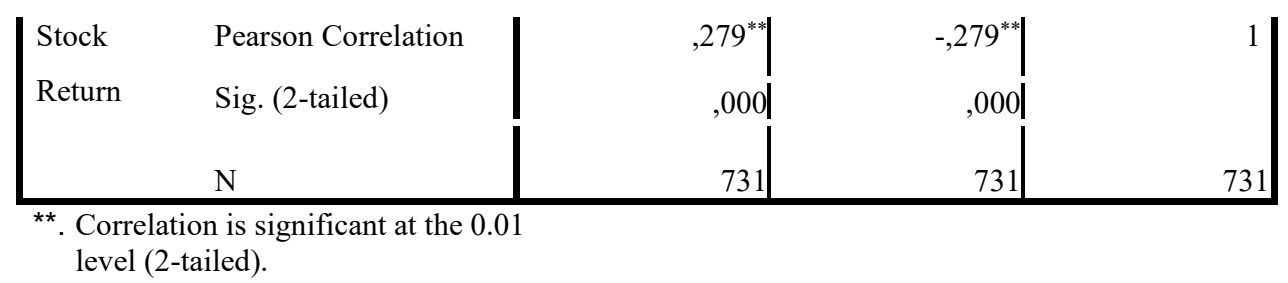

From the results of simple correlation analysis (r) foreign transactions obtained Pvalue $(\mathrm{Sig}=0,000)<0.05$, then $\mathrm{H} 0$ is rejected, so there is a correlation of foreign transactions to changes in stock returns with (r) is 0.279 . From these results indicate that there is a relationship but low between foreign transactions on stock returns because it is in the range of $0.20-0.399$. However, the direction of the relationship is positive because the value of $\mathrm{r}$ is positive, which means an increase in foreign transactions will trigger an increase in stock returns. For domestic transactions obtained Pvalue $(\mathrm{Sig}=0,000)<0.05$, then $\mathrm{H} 0$ is rejected, so there is a correlation of domestic transactions to changes in stock returns with (r) is -0.279 . From these results it shows that there is a relationship but it is low. But the direction of the relationship is negative because the value of $r$ is negative, which means an increase in domestic transactions will trigger a decrease in stock returns.

\subsubsection{Trade, Services and Investment Sector}

Correlation test results and hypothesis testing from the Trade, Services and Investment sectors, researchers present in the table as follows:

Table 6. Trade, Service and Investment Correlation Test Results

\begin{tabular}{|c|c|c|c|c|}
\hline & & $\begin{array}{l}\text { Foreign } \\
\text { Transaction }\end{array}$ & $\begin{array}{l}\text { Domestic } \\
\text { Transaction }\end{array}$ & $\begin{array}{l}\text { Stock } \\
\text { Return }\end{array}$ \\
\hline \multirow{3}{*}{$\begin{array}{l}\text { Foreign } \\
\text { Transaction }\end{array}$} & Pearson Correlation & 1 & $-1,000^{* *}$ &,$- 094^{*}$ \\
\hline & & &, 000 &, 011 \\
\hline & $\begin{array}{l}\text { Sig. (2-tailed) } \\
\mathrm{N}\end{array}$ & 731 & 731 & 731 \\
\hline \multirow{3}{*}{$\begin{array}{l}\text { Domestic } \\
\text { Transaction }\end{array}$} & Pearson Correlation & $-1,000^{* *}$ & 1 &, $094^{*}$ \\
\hline & Sig. (2-tailed) & 000, & & 011 \\
\hline & $\mathrm{N}$ & 731 & 731 & 731 \\
\hline \multirow{3}{*}{ Stock Return } & Pearson Correlation &,$- 094^{*}$ &, $094^{*}$ & 1 \\
\hline & Sig. (2-tailed) & ,011 & ,011 & \\
\hline & $\mathrm{N}$ & 731 & 731 & 731 \\
\hline
\end{tabular}

††. Correlation is significant at the 0.01

level (2-tailed). *. Correlation is

significant at the 0.05 level (2-tailed). 
From the results of simple correlation analysis (r) foreign transactions obtained Pvalue $(\mathrm{Sig}=0.011)>0.05$, then $\mathrm{H} 0$ is accepted, so there is no transaction correlation foreign exchange changes to stock returns with $(r)$ is -0.057 . For domestic transactions, it is found that P-value $(\mathrm{Sig}=0.011)>0.05$, then $\mathrm{H} 0$ is accepted, so there is no correlation of domestic transactions with changes in stock returns with (r) is 0.094. From these results we can conclude that there are no foreign transactions, domestic transactions related to stock returns in the Trade, Services and Investment Sector. Researchers also make a comparison of the results of the correlation test between sectors can be seen in the table below.

Table 4.16 Comparison of Cross-Sector Correlation Test Results

\begin{tabular}{|c|c|c|c|c|c|c|c|c|c|}
\hline \multirow{2}{*}{\multicolumn{2}{|c|}{ Information }} & \multicolumn{2}{|c|}{ PRK } & \multicolumn{2}{|c|}{ I UT } & \multicolumn{2}{|c|}{$\mathbf{K}$} & \multicolumn{2}{|c|}{ PJI } \\
\hline & & $\mathbf{F}$ & D & $\mathbf{F}$ & D & $\mathbf{F}$ & D & $\mathbf{F}$ & D \\
\hline \multirow{3}{*}{$\mathbf{S}$} & $\begin{array}{l}\text { Pearson } \\
\text { Correlation }\end{array}$ & 0,041 & $-0,041$ & 0,039 & $-0,039$ & 0,279 & $-0,279$ & $-0,094$ & 0,094 \\
\hline & $\begin{array}{l}\text { Sig. } \\
\text { (2tailed) }\end{array}$ & 0,271 & 0,271 & 0,287 & 0,287 & 0,000 & 0,000 & 0,011 & 0,011 \\
\hline & $\mathbf{N}$ & 731 & 731 & 731 & 731 & 731 & 731 & 731 & 731 \\
\hline & $\begin{array}{ll}\text { Exp: } & \\
& \text { PRK } \\
& \text { IUT } \\
& \text { K } \\
& \text { PJI } \\
& \text { F } \\
& \text { D }\end{array}$ & $\begin{array}{l}=\text { Prop } \\
=\text { Infra } \\
=\text { Finar } \\
=\text { Trad } \\
=\text { Forei } \\
=\text { Dom }\end{array}$ & $\begin{array}{l}\text {, Real } \\
\text { icture, } \\
\text { Sector } \\
\text { ervice, }\end{array}$ & $\begin{array}{l}\text { dan } B \\
\text { y dan } \\
\text { nvestn }\end{array}$ & $\begin{array}{l}\text { Ing Con } \\
\text { nsporta } \\
\text { t Sector }\end{array}$ & $\begin{array}{l}\text { Iction S } \\
\text { Sector }\end{array}$ & & & \\
\hline
\end{tabular}

From the table above we can conclude, that which has a relationship to stock returns is the financial sector where sig $<0.05$, but the correlation is still low because it is in the range of $0.20-0.399$. But the direction of the relationship is positive because the value of $r$ is positive, which means an increase in foreign transactions will trigger an increase in stock returns. For domestic transactions the direction of the relationship is negative because the value of $r$ is negative, which means an increase in domestic transactions will trigger a decrease in stock returns. For sector companies Property, Real estate and Building Construction, Sector

Infrastructure, Utilities and Transportation and Trade, Services and Investment Sectors from the correlation results sig $>0.05$ found there is no relationship between foreign transactions, domestic transactions on stock returns.

\subsubsection{Correlation between Sectors}

The results of the correlation test between sub-sectors: 
Table 7. Comparison of Correlation Test Results Between Sectors

\begin{tabular}{|c|c|c|c|c|c|c|c|}
\hline \multirow{3}{*}{ No } & \multirow{3}{*}{ Sector } & \multicolumn{6}{|c|}{ Return Saham } \\
\hline & & \multicolumn{2}{|c|}{ Pearson Correlation } & \multicolumn{2}{|c|}{ Sig. (2-tailed) } & \multicolumn{2}{|c|}{$\mathbf{N}$} \\
\hline & & $\mathbf{F}$ & $\mathbf{D}$ & $\mathbf{F}$ & D & $\mathbf{F}$ & D \\
\hline \multicolumn{8}{|c|}{ Property, Real estate and Building Construction Sector } \\
\hline 1 & $\begin{array}{l}\text { Property and Real Estate Sub } \\
\text { Sector }\end{array}$ & 0,039 & $-0,039$ & 0,289 & 0,289 & 731 & 731 \\
\hline 2 & Building Construction Sub Sector & 0,201 & $-0,201$ & 0,000 & 0,000 & 731 & 731 \\
\hline \multicolumn{8}{|c|}{ Infrastructure, Utilities and Transportation Sector } \\
\hline 3 & Energy Sub Sector & 0,203 & $-0,203$ & 0,000 & 0,000 & 731 & 731 \\
\hline 4 & $\begin{array}{l}\text { Toll Road, } \\
\text { Ports, Airports and the like Sub } \\
\text { Sector }\end{array}$ & 0,010 & $-0,010$ & 0,576 & 0,576 & 731 & 731 \\
\hline 5 & Telecommunication Sectors & 0,207 & $-0,207$ & 0,000 & 0,000 & 731 & 731 \\
\hline 6 & Transportation Sub Sectors & $-0,044$ & 0,044 & 0,232 & 0,232 & 731 & 731 \\
\hline 7 & $\begin{array}{l}\text { Non Building Constructions Sub } \\
\text { Sectors }\end{array}$ & 0,009 & 0,009 & 0,817 & 0,817 & 731 & 731 \\
\hline \multicolumn{8}{|c|}{ Sektor Keuangan } \\
\hline 8 & Bank Sub Sectors & 0,293 & $-0,293$ & 0,000 & 0,000 & 731 & 731 \\
\hline 9 & Financial Institution Sub Sectors & $-0,059$ & 0,059 & 0,111 & 0,111 & 731 & 731 \\
\hline 10 & Securities Company Sub Sectors & 0,000 & $-0,000$ & 0,990 & 0,990 & 731 & 731 \\
\hline 11 & Insurance Sub Sectors & 0,008 & $-0,008$ & 0,835 & 0,835 & 731 & 731 \\
\hline \multicolumn{8}{|c|}{ Sektor Perdagangan, Jasa dan Investasi } \\
\hline 12 & Large Trade Sub Sectors & $-0,018$ & 0,018 & 0,626 & 0,626 & 731 & 731 \\
\hline 13 & Retail Trade Sub Sectors & $-0,033$ & 0,033 & 0,370 & 0,370 & 731 & 731 \\
\hline 14 & $\begin{array}{l}\text { Restaurants, Hotels and Tourism Sub } \\
\text { Sectors }\end{array}$ & $-0,057$ & 0,057 & 0,122 & 0,122 & 731 & 731 \\
\hline 15 & $\begin{array}{l}\text { Advertising, Printing dan Media Sub } \\
\text { Sectors }\end{array}$ & 0,065 & $-0,065$ & 0,080 & 0,080 & 731 & 731 \\
\hline 16 & Health Sub Sectors & 0,081 & $-0,081$ & 0,028 & 0,028 & 731 & 731 \\
\hline 17 & $\begin{array}{l}\text { Computer Services and Other } \\
\text { Devices Sub Sectors }\end{array}$ & 0,077 & $-0,077$ & 0,037 & 0,037 & 731 & 731 \\
\hline 18 & Investment Company Sub Sectors & $-0,069$ & 0,069 & 0,061 & 0,061 & 731 & 731 \\
\hline 19 & Other Trade Sub Sectors & $-0,172$ & 0,172 & 0,000 & 0,000 & 731 & 731 \\
\hline
\end{tabular}

\section{Ket: $\mathbf{F}=$ Foreign $\quad \mathbf{D}=$ Domestik}

From the table above we can conclude that there are 5 out of 19 service sector subsectors that have a correlation between foreign transactions and domestic transactions on stock returns, but the average relationship is still low because it is in the range of $0,200,399$, but for foreign transactions the direction of the relationship is positive. However, in domestic transactions the direction of the relationship is negative. The sub-sectors that have correlation are the construction sub-sector, the energy sub-sector, the telecommunications sub-sector, the bank sub-sector, and other trade sub-sectors. From these results we can conclude that from all sub-sectors the correlation results obtained more do not have a correlation than those who have a correlation. 
Foreign transactions in service sector companies on the Indonesia Stock Exchange in 2016-2018 are more nominated by selling actions which are marked by negative net buy of the utility infrastructure sector, transportation is a sector that has a very large turnover of foreign funds in the amount of - $\mathrm{Rp} 24$ trillion, but investors foreigners dominate capital outflows in the form of selling. Further explored sub-sectors that most did the selling took place in the telecommunications company sub-sector in the amount of -Rp 9 trillion. Quoted from Yuniar [7] which was reported on October 11, 2017 which said a number of shares were depressed in the telecommunications sector in stock trading this week. The selling of foreign investors is considered to be one of the drivers of pressure on the shares of telecommunications issuers. The factors driving the sale of foreign investors are not yet clear enough, if viewed from the fundamentals, PT Telekomunikasi Indonesia Tbk, recorded a good performance. But it is different for companies in the financial sector and trade sector, services, investment, foreign investors still entrust their funds to be invested in this company sector. Foreign transactions still dominate the buying action by showing a positive net buy of $\mathrm{Rp} 11$ trillion. This is inseparable from the development of fintech in the financial system that will produce new products, services and business models and can have an impact on monetary stability, financial system stability, efficiency, smoothness and reliability of the payment system. So that foreign investors still entrust their funds to be invested in the sector and there are also several LQ 45 companies in the financial sector such as Bank Central Asia Tbk, Bank Rakyat Indonesia Tbk and others.

Then quoted from www.cnbcindonesia.com [8] which was released March 28, 2018 and then a massive sell-off by foreign investors because foreign investors seemed disappointed because the Indonesian economy was growing at a low level. Throughout 2017, the world economy is projected to grow by $3.7 \%$ by the International Monetary Fund (IMF) but the increase in Indonesia's economic growth is only $0.04 \%$ (from $5.03 \%$ to $5.07 \%$ ). When compared with neighboring countries, Thailand was able to drive economic growth to the level of $3.9 \%$ last year, up to $0.7 \%$ from the achievements in 2016 which amounted to $3.2 \%$. Then, Malaysia's economy grew by 5.9\% last year, skyrocketing compared to 2016's achievements of $4.22 \%$. Viewed from neighboring countries, it is clear that Indonesia has lower economic growth, so it is not wrong if investors are disappointed with Indonesia's achievements in 2017.

From the results of the correlation test that researchers did. Of the 19 sub-sectors of the company in the service sector companies, obtained 5 sub-sectors of the company from the foreign transaction correlation test have a relationship to stock returns but the average relationship is low and 14 other sub-sectors do not have a relationship to stock returns as can be seen in the table 7 . Then, from the 4 service sector companies one company sector from the results of the correlation test there is a relationship between foreign transactions and stock returns, namely in the financial sector but the relationship is still low which can be seen in table 6. then from the overall correlation test results in the service sector there is a relationship between foreign transactions on stock returns, with a very low relationship with the value of $r$ shows a positive value that can be seen in table 5, which means the higher the foreign transaction the higher the increase in stock returns and vice versa if the lower the foreign transaction, the higher the decline in stock returns. This is due to the high volume of funds invested by foreign parties in the Indonesian capital market so that it will be worried if foreign parties withdraw their capital from the Indonesian capital market. With the high number of transactions conducted by foreign parties in the Indonesian capital market, foreign investors believe in the performance of Indonesian companies. So that in the end the high and low of foreign transactions on the Indonesian capital market will affect stock returns. 
The results of this study are consistent with research conducted by [1] that examines whether how much influence the investment activities carried out by foreign investors on the movement of stock returns obtained by the results of the study indicate that there is a significant relationship between the value of foreign investor transactions on returns stock. Other research that is consistent with this research is a study conducted by Fitriani (2015)[3] who examined whether the percentage of foreign share capital ownership, dividends, sales growth, market risk and market return affect stock prices. The results of his research showed the percentage of foreign ownership and dividends had a positive effect on stock prices.

Domestic transactions in service sector companies on the Indonesia Stock Exchange in 2016-2018 are more nominated by buying actions marked by positive net buy, namely in property, real estate, building construction and utility infrastructure, transportation sectors. Where the highest buying action occurred in the infrastructure, utilities and transportation sectors, amounting to Rp 24 trillion. If we explore further from the service companies sub sector, the property and real estate companies sub sector is the most desirable by domestic investors with a net buy of Rp. 8.9 trillion and then followed by the telecommunications company sub sector amounting to Rp. 8.6 trillion. This is inseparable from the development of Indonesia's infrastructure that continues to increase especially since the government is currently very intensively to carry out infrastructure development such as bridges and others, so that domestic investors see the opportunity to invest in shares in the sector. In the telecommunications sector, as quoted from www.kontan.co.id, which was released on October 3,2017 , the infrastructure sector stock index rose by $15.15 \%$, it cannot be separated from the flashy performance of telecommunications companies such as PT Telekomunikasi Indonesia Tbk , PT XL Axiata Tbk and also PT Jasa Marga Tbk which became the driving force of the index of companies in this sector so that domestic investors invest their capital in these sector companies even though foreign parties take more selling action. Then in the financial sector and the trade, services, investment sector, the selling action was still nominated for Rp. 11 trillion.

Investors believe that the shares of the infrastructure sector in utilities, transportation and property, real estate will provide high stock returns because of the high development taking place in Indonesia itself and the high demand for property in society and the desire of people wanting to own their own homes. The buying action was also influenced by the factor of foreign foreign investors to sell in the company sector so that domestic investors buy shares that have been sold abroad in the hope that they will return if they invest in the company sector. Because if foreign funds leave the capital market, the market will be shaken, but withdrawals by foreign parties do not reduce the optimism of domestic investors to invest in the capital market.

From the results of the correlation test conducted by researchers, from 19 sub-sectors of companies in the service sector companies, get 7 sub-sectors of the company from the domestic transaction correlation test has a relationship to stock returns but the average relationship is very low and 12 other sub-sectors have no relationship to stock returns as can be seen in table 7 . Then, from the 4 service sector companies one company sector from the results of the correlation test there is a relationship between foreign transactions and stock returns, namely in the financial sector but the relationship is still low which can be seen in table 6. then from the overall correlation test results in the service sector there is a relationship between foreign transactions to stock prices, with a very low relationship with the value of $r$ shows a negative value that can be seen in table 5, which means the higher the domestic transaction, the higher the decline in stock returns and vice versa. This happens because if foreign investors do capital outflows, domestic investors do capital inflow. The withdrawal of 
funds by foreign parties apparently did not affect the interest of domestic investors to invest in the Indonesian capital market.

The results of this study are consistent with research conducted by Manggal (2013)[6] that examines whether the behavior of local investors who engage in a strategy of following a foreign stock transaction will affect stock prices. The results of his research indicate that domestic investor transactions affect the rising or falling stock prices.

\section{Conclusion}

Based on the results of quantitative associative research with causal relationships conducted at service sector companies listed on the Indonesia Stock Exchange (IDX) in the 2016-2018 period concerning the relationship of foreign transactions and domestic transactions to stock returns, conclusions can be drawn. The conclusion is presented as follows:

1. In accordance with the data obtained by researchers, the relationship of foreign transactions to stock returns, the conclusion is that there is a relationship between foreign transactions and stock returns in service sector companies but the relationship is still very low and the direction of the positive relationship, an increase in foreign transactions will trigger an increase in stock returns and vice versa.

2. The relationship of domestic transactions to stock returns, the conclusion is there is a relationship between foreign transactions on stock returns in service sector companies but the relationship is still very low with a negative relationship direction, an increase in domestic transactions will trigger a decrease in stock returns and vice versa 


\section{References}

[1] W. Adjie, "Transaksi Investor Asing Terhadap Return Saham Dengan Makroekonomi Sebagai Variabel Eksogen Pada Bursa Efek Indonesia Periode 2003 - 2013,” pp. 1103, 2014.

[2] E. Tandelilin, "Portofolio dan Investasi Teori dan Aplikasi," Yogyakarta: Kanisius, pp. 1-387, 2010.

[3] M. Fitriani, "Pengaruh Persentase Kepemilikan Modal Saham Asing, Deviden, Pertumbuhan Penjualan, Risiko Pasar, dan Return Market Terhadap Harga Saham Pada Perusahaan yang Masuk ke Dalam ISSI 2011-2013,” Universitas Islam Negeri Sunan Kalijaga, 2014.

[4] R. Elvira, "Pengaruh Aktifitas Perdagangan Terhadap Return Saham Syariah Perusahaan yang Listing di Jakrta Islamix Index (JII) Periode 2012-2014," ejournal madania, vol. 20, no. 1, pp. 101-114, 2014.

[5] E. Fransiska, "Pengaruh Perdagangan Investor Asing Terhadap Harga Saham Di Bursa Efek Indonesia," 2013.

[6] B. Manggala, "Pengaruh Transaksi Investor Asing Terhadap Nilai Saham Yang Dimoderasi Oleh Transaksi Investor Lokal," pp. 1-41, 2013.

[7] “Dua Saham Emiten Telekomunikasi Tertekan, Ada Apa?," 2017. [Online]. Available: https://www.liputan6.com/bisnis/read/3125249/dua-saham-emiten-telekomunikasitertekan-ada-apa.

[8] K. Anthony, “Kenapa Investor Asing Keluar dari Pasar Saham Domestik?,” 2018. [Online]. Available: Kenapa Investor Asing Keluar dari Pasar Saham Domestik? 